\title{
HUBUNGAN GANGGUAN KENYAMANAN FISIK DAN PENYAKIT DENGAN KUALITAS TIDUR IBU HAMIL TRIMESTER III
}

\author{
Mariyam Ulfa Sukorini \\ Departemen Epidemiologi, Fakultas Kesehatan Masyarakat \\ Universitas Airlangga, Surabaya, Jawa Timur, Indonesia \\ Alamat Korespondensi: \\ Mariyam Ulfa Sukorini \\ Email: mariyamulfa70@gmail.com
}

\begin{abstract}
The older the stages of pregnancy, it was more likely for pregnant women to experience sleep disorder which usually cause physical discomfort and desease (Prasadja, 2009). Poor sleep disorders can cause complications in pregnancy. This study aims to assess the relationship between physical discomfortand presence of disease with sleep quality of women in third trimester of pregnancy. Dependent variable is sleep quality, while Independent variables were pyshical discomfortand presence of disesas. This study used cross-sectional study design and total sampling technique. A total of 36 respondents gathered from Puskesmas Gading 's pregnant women population. PSQI quetionaire used to assess sleep quality (cronbach's alpha $=0.83$ ) and physical discomfort quetionaire (cronbach's alpha $=0.672$ ). Every quetionaire's validity has been tested with $r$-count $>0.707$. All of the data then processed by cross-tabulation and Pearson test. The result of this study showed that most of the respondents have poor sleep quality (53\%). Statistical tests showed poor correlation $(r=0.363)$ between physical discomfort and sleep quality. Furthermore, poor relationship found in pregnant women with disease $(r=0.334)$.
\end{abstract}

Keywords: physical discomfort, pregnant woman, sleep quality, disease

\begin{abstract}
ABSTRAK
Semakin besar umur kehamilan, ibu hamil akan mengalami gangguan tidur (Prasadja, 2009). Ibu hamil yang mengalami gangguan tidur umumnya terjadi karena adanya perubahan dalam kehamilan sehingga menimbulkan ketidaknyamanan fisik. Ibu yang menderita penyakit dapat pula mengalami gangguan tidur. Gangguan tidur yang buruk dapat mengakibatkan komplikasi kehamilan (Okun, 2011). Tujuan penelitian ini adalah mengetahui hubungan gangguan kenyamanan fisik dan penyakit dengan kualitas tidur ibu hamil trimester III. Variabel dependen pada penelitian ini adalah kualitas tidur, sedangkan variabel independen yakni gangguan kenyamanan fisik dan penyakit. Penelitian dengan desain studi cross sectional ini menggunakan populasi ibu hamil trimester III yang bertempat tinggal di wilayah kerja Puskesmas Gading. Tehnik sampling menggunakan total populasi dengan sampel 36 responden. Penelitian dengan kuesioner Pittsburgh Sleep Quality Index (PSQI) untuk mengetahui kualitas tidur (cronbach alfa 0,83), dan kuesioner gangguan kenyamanan fisik (cronbach alfa 0,673). Kuesioner telah di uji validitas dengan r-hitung $>0,707$. Data diolah dengan crosstab dan dianalisis dengan korelasi Pearson. Hasil penelitian menunjukkan sebagian besar responden mempunyai kualitas tidur buruk (53\%). Hasil uji statistik didapatkan adanya hubungan yang rendah $(0,363)$ antara gangguan kenyamanan fisik dan kualitas tidur ibu hamil. Selain itu penyakit yang diderita ibu hamil juga menunjukkan hubungan yang rendah $(0,334)$.
\end{abstract}

Kata kunci: gangguan kenyamanan fisik, ibu hamil, kualitas tidur, penyakit 


\section{PENDAHULUAN}

Salah satu kebutuhan dasar manusia adalah istirahat dan tidur. Istirahat dan tidur diperlukan agar otak dan tubuh dapat memperbaiki dirinya sendiri, sehingga bila seseorang kurang tidur akan segera tampak berbagai kelainan fisik maupun mental. Pada saat tidur kerja tubuh melambat, sehingga membuat sel-sel penyembuh untuk memperbaiki sel-sel yang rusak (Prasadja, 2009). Kebutuhan tidur tiap individu berbeda-beda termasuk ketika hamil (Asmadi, 2008).

Pada kehidupan perempuan terdapat fase kehamilan yang merupakan masa-masa terjadinya perubahan yang besar. Perubahan ini tidak hanya berhubungan dengan perubahan fisik, namun juga perubahan biokimia, fisologis, bahkan psikologis yang merupakan konsekuensi dari pertumbuhan janin dalam rahim. Terjadinya perubahan pada ibu hamil ini untuk menjaga metabolisme tubuh, mendukung pertumbuhan janin, serta persiapan persalinan dan menyusui dengan tingkatan yang bervariasi di setiap trisemesternya (Emilia, 2010).

Kehamilan dibagi menjadi tiga trimester. Ketika memasuki trimester III atau umur kehamilan semakin bertambah, semakin banyak keluhan yang dirasakan oleh ibu baik keluhan yang bersifat psikis maupun fisik dan memiliki dampak pada kualitas tidur ibu hamil. Beberapa faktor seperti semakin membesarnya ukuran perut ibu, gerakan janin di dalam kandungan yang semakin aktif, yang membuat ibu hamil kesulitan untuk tidur di malam hari (Aprilia, 2014).

Mendekati saat melahirkan, ibu hamil akan sulit mengatur posisi tidur. Gangguan ini dapat disebabkan karena semakin besar kehamilan sehingga diafragma akan tertekan ke atas dan mengganggu pernafasan. Pada ibu hamil disarankan untuk tidur dengan posisi miring kiri atau posisi yang membuat nyaman ibu hamil.

Pernafasan yang tidak baik pada ibu hamil akan berpengaruh pada berkurangnya pasokan oksigen pada otak sehingga dapat memengaruhi kualitas tidur (Emilia, 2010). Masalah lain yang umum selama kehamilan adalah nyeri ulu hati, atau bisa disebut sebagai penyakit gastroesophageal reflux (GERD) yakni asam lambung berbalik kembali ke esofagus (Ayudhitya dan Tjuataja, 2014). Umumnya pada trimester III atau menjelang persalinan gangguan tidur mencapai puncaknya (Prasadja, 2009).

Lee (2004), melakukan penelitian tentang kualitas tidur pada ibu hamil dan menyatakan bahwa ibu hamil yang tidur kurang dari 6 jam per malam memiliki risiko operasi caesar 4,5 kali lebih besar. Penelitian yang dilakukan oleh William et al (2010), menunjukkan hasil bahwa ibu hamil yang tidur kurang dari 5 jam tiap malam berisiko meningkatkan tekanan darah dan berakibat pada hipertensi.

Ibu hamil yang memiliki kualitas tidur yang buruk dapat mengakibatkan beberapa komplikasi dalam kehamilan, seperti pada penelitian yang dilakukan oleh Okun (2011), yang menyatakan bahwa gangguan tidur yang terjadi pada ibu hamil dapat memperburuk respons inflamasi tubuh dan menyebabkan kelebihan produksi sitokin. Sitokin adalah molekul yang berhubungan dengan sel-sel kekebalan. Bila tubuh mengalami kelebihan sitokin maka dapat mengganggu arteri tulang belakang yang mengarah ke plasenta, menyebabkan penyakit pembuluh darah, dan kelahiran bayi prematur.

Menurut National Sleep Foundation (2007) dalam Rezaei (2015), perempuan hamil yang mengalami beberapa bentuk gangguan tidur mencapai $79 \%$. Sebanyak $72 \%$ dari ibu hamil akan mengalami frekuensi terbangun lebih sering pada malam hari. Umumnya kebutuhan tidur orang dewasa yakni selama 7-8 jam, namun untuk ibu hamil bisa mencapai 10 jam. Hal ini tergantung pada umur saat ibu hamil dan stamina yang dirasakan ibu. Kualitas tidur yang baik akan menjaga kesehatan ibu selama hamil serta memberikan cukup energi saat persalinan. Penelitian yang dilakukan oleh Komalasari 
et al (2012), di Jatinangor mengenai kualitas tidur ibu hamil trimester III didapatkan hasil bahwa sebanyak $72,2 \%$ dari $54 \mathrm{ibu}$ hamil yang diteliti memiliki kualitas tidur yang buruk dan terdapat hubungan yang bermakna antara tingkat kecemasan dengan kualitas tidur ibu hamil. Sejalan dengan penelitian yang dilakukan Komalasari et al (2012), penelitian yang dilakukan oleh Andari (2013), di Medan juga menunjukkan bahwa $63 \%$ dari 41 ibu hamil mempunyai kualitas tidur yang buruk karena perubahan fisiologis dan psikologis yang dialami ibu ketika hamil.

Data menurut Profil Kesehatan Jawa Timur tahun 2014 didapatkan hasil masih banyak komplikasi dalam kehamilan. Komplikasi kehamilan tertinggi di Jawa Timur adalah di Kota Surabaya (Dinkes Provinsi Jawa Timur, 2014) yang mencapai 9513 kasus. Tahun 2015 diperkirakan ibu hamil yang mengalami komplikasi sebesar 6526 orang.

Wilayah di Kota Surabaya yang memiliki komplikasi ibu hamil tertinggi terletak di Puskesmas Gading yakni terjadi komplikasi kehamilan sebesar 268 kasus (Dinkes Surabaya, 2015). Puskesmas Gading melingkupi 3 kelurahan yakni Kelurahan Gading, Kelurahan Kapas Madya baru, dan Kelurahan Rangkah. Dari data tahun 2016 dari bulan Januari sampai November komplikasi yang terjadi pada ibu hamil tertinggi yakni di Kelurahan Gading yakni untuk kasus hipertensi dalam kehamilan sebanyak 23 kasus dalam Kehamilan. Akibat dari komplikasi-komplikasi tersebut 14 kasus diantaranya merupakan partus prematur. Tahun 2016 dari bulan Januari sampai November di Puskesmas Gading juga terdapat Angka Kematian Ibu (AKI) sebanyak 1 kasus yang terdapat di Kelurahan Gading.

Penelitian ini dilakukan untuk menganalisis hubungan gangguan kenyamanan fisik, tingkat kecemasan dan penyakit dengan kualitas tidur ibu hamil trimester III di wilayah kerja Puskesmas Gading Kota Surabaya tahun 2016.

\section{METODE PENELITIAN}

Penelitian ini menggunakan desain penelitian cross sectional, yakni penelitian yang dilakukan terhadap paparan (exposure) dan (disease outcome) secara bersama pada setiap subjek penelitian (Swarjana, 2012). Desain Cross Sectional, dilakukan dengan cara mengidentifikasi dan mengukur kualitas tidur ibu hamil di Puskesmas Gading Kota Surabaya pada waktu hanya satu kali pada satu saat tanpa adanya follow up, kemudian di hubungan dengan gangguan kenyamanan fisik dan penyakit.

Populasi adalah semua wanita hamil trimester III (umur kandungan 28-40 minggu) yang bertempat tinggal di wilayah kerja Puskesmas Gading Kota Surabaya sebesar 36 ibu hamil. Sampel merupakan total populasi, dengan jumlah 36 ibu hamil. Penelitian ini dilakukan di wilayah kerja Puskesmas Gading Kota Surabaya yakni di Kelurahan Gading kecamatan Tambaksari Kota Surabaya. Waktu penelitian adalah bulan Agustus sampai Desember 2016.

Pengukuran Kualitas tidur ibu hamil trimester III menggunakan alat ukur (instrumen) yang dikenal dengan The Pittsburgh Sleep Quality Index (PSQI) dengan cronbach alfa 0,83. Gangguan kenyamanan fisik pada ibu hamil di ukur berdasarkan kuesioner oleh Iriana (2013) dengan cronbach alfa 0,673.

Setelah data terkumpul kemudian dilakukan pengolahan data dengan Editing, Coding, Scoring, Tabulasi data. Data diolah dengan tabulasi silang dan analisis Pearson.

\section{HASIL}

\section{Karakteristik Responden}

Responden dalam penelitian ini adalah ibu hamil trimester III yang bertempat tinggal di wilayah kerja Puskesmas Gading, tepatnya di Kelurahan Gading yakni 
sebanyak 36 orang. Tabel 1 menunjukkan bahwa hampir seluruh ibu hamil berumur 20-35 tahun yakni sebanyak 30 ibu hamil $(83,3 \%)$. Umur yang ideal untuk hamil dan melahirkan adalah umur 20-35 tahun. Umur 20-35 tahun memiliki risiko yang lebih rendah untuk terjadinya komplikasi dalam kehamilan maupun persalinan.

Tabel 1. Distribusi Frekuensi Karakteristik Ibu Hamil Trimester III di Wilayah Kerja Puskesmas Gading Kota Surabaya Tahun 2016

\begin{tabular}{lcrr}
\hline Variabel Bebas & \multicolumn{1}{c}{ Kategori } & F & \% \\
\hline Umur & $<20$ tahun & 2 & 5,6 \\
\cline { 2 - 4 } & $20-35$ tahun & 30 & 83,3 \\
\cline { 2 - 4 } & $>35$ tahun & 4 & 11,1 \\
\hline Pendapatan & $>3.000 .000$ & 20 & 55,6 \\
keluarga & $<3.000 .000$ & 16 & 44,4 \\
\hline Graviditas & $\begin{array}{c}\text { Kehamilan } \\
\text { pertama }\end{array}$ & 7 & 19,4 \\
\cline { 2 - 4 } & $>1$ kali hamil & 29 & 80,6 \\
\hline
\end{tabular}

Pendapatan keluarga menunjukkan persentase yang hampir sama antara ibu hamil yang mempunyai pendapatan keluarga kurang dari Rp 3.000.000 per bulan dan lebih besar sama dengan Rp 3.000.000 per bulan. Pendapatan keluarga ibu hamil paling besar pada ibu hamil dengan pendapatan keluarga lebih dari sama dengan Rp 3.000.000 per bulan yakni sebanyak 20 ibu hamil (55,6\%). Hasil penelitian menunjukkan penghasilan keluarga telah sesuai dengan Upah Minimum Regional (UMR) kota Surabaya sehingga dianggap tercukupi kebutuhan ekonomi keluarga di Surabaya.

Hampir seluruh ibu hamil yang menjadi responden penelitian adalah ibu dengan kehamilan lebih dari satu kali atau multigravida yakni sebanyak 29 ibu hamil (80,6\%). Hasil penelitian menunjukkan hampir seluruh ibu hamil telah mempunyai pengalaman kehamilan sebelumnya.

\section{Gangguan Kenyamanan Fisik}

Gangguan kenyamanan fisik merupakan sensasi tubuh yang dirasakan ibu hamil. Gangguan kenyamanan fisik yang sering terjadi pada ibu hamil akan semakin berat sejalan dengan usia kehamilan dan dapat mengganggu aktivitas sehari-hari.

Tabel 2 menunjukkan bahwa ibu hamil trimester III memiliki gangguan fisik ringan yang artinya tidak mengganggu aktivitas sehari-hari yakni sebanyak 28 ibu hamil (78\%).

Tabel 2. Distribusi Frekuensi Gangguan Kenyamanan Fisik Ibu Hamil Trimester III di Wilayah Kerja Puskesmas Gading Kota Surabaya Tahun 2016

\begin{tabular}{|c|c|c|}
\hline $\begin{array}{c}\text { Gangguan kenyamanan } \\
\text { Fisik }\end{array}$ & $\mathbf{F}$ & $\%$ \\
\hline Tidak ada gangguan & 5 & 14 \\
\hline Gangguan fisik ringan & 28 & 78 \\
\hline Gangguan fisik berat & 3 & 8 \\
\hline
\end{tabular}

Ibu hamil trimester III pada penelitian ini mengalami gangguan kenyamanan fisik ringan seperti sering buang air kecil, nyeri pinggang maupun cepat lelah yang tidak mengganggu aktivitas ibu hamil.

\section{Penyakit}

Penyakit merupakan keadaan tidak normal dalam tubuh sehingga mengganggu aktivitas sehari-hari. Penyakit terjadi bila ada perubahan dari nilai rata-rata normal yang telah ditetapkan sehingga diagnosisnya ditentukan oleh medis.

Tabel 3 menunjukkan bahwa ibu hamil trimester III tidak memiliki penyakit yakni sebanyak 32 ibu hamil (88,9\%). Sebagian kecil Ibu hamil yang memiliki penyakit yakni 4 ibu hamil (11,1\%).

Ibu hamil yang menderita penyakit dalam penelitian ini hanya 4 orang dengan macam penyakit yang diderita ibu hamil yakni asma, hipetensi dan anemia. 
Kualitas Tidur Ibu Hamil Timester III

Ibu hamil membutuhkan tenaga lebih banyak daripada ibu yang tidak sedang hamil. Penting bagi ibu hamil untuk memulihkan tenaga setelah beraktivitas dengan istirahat atau tidur.

Tabel 4 menunjukkan persentase yang hampir mirip antara ibu yang memiliki kualitas tidur baik maupun buruk. persentase ibu hamil trimester III yang memiliki kualitas tidur yang buruk yakni 19 ibu hamil $(52,8 \%)$.

Tabel 4. Distribusi Frekuensi Kualitas Tidur Ibu Hamil Trimester III di Wilayah Kerja Puskesmas Gading Kota Surabaya Tahun 2016

\begin{tabular}{lcc}
\hline \multicolumn{1}{c}{ Kualitas Tidur } & F & \% \\
\hline Baik & 17 & 47,2 \\
Buruk & 19 & 52,8 \\
\hline
\end{tabular}

Ibu hamil trimester III umumnya mengalami gangguan tidur. Dalam penelitian ini ibu hamil yang memiliki kualitas tidur buruk memiliki jumlah jam tidur yang masih kurang yakni kurang dari 5 jam per hari, gangguan kualitas tidur ini semakin meningkat sesuai dengan usia kehamilan.

\section{Hubungan Variabel Bebas dengan Kualitas Tidur Ibu Hamil}

Umur ibu hamil yang ideal untuk hamil dan melahirkan yakni di umur 20-35 tahun. Ketika umur ibu hamil kurang dari 20 tahun maupun lebih dari 35 tahun maka masuk dalam umur risiko tinggi

Tabel 5 menunjukkan persentase yang hampir sama untuk terjadinya kualitas tidur buruk maupun baik di semua umur, baik pada umur ideal maupun rawan. Hasil penelitian diketahui 53,3\% dari ibu hamil yang berumur ideal (20-35 tahun) justru mengalami kualitas tidur yang buruk.

Pendapatan keluarga sangat penting untuk memenuhi kebutuhan kehamilan dan persalinan. Hasil penelitian menunjukkan bahwa $62,5 \%$ ibu hamil dengan pendapatan keluarga kurang dari Rp 3.000.000 per bulan mengalami kualitas tidur yang baik.

Ibu hamil primigravida umumnya belum memiliki pengalaman melahirkan sebelumnya. Ibu yang telah lebih dari satu kali hamil telah memiliki pengalaman

Tabel 5. Hubungan Variabel Bebas dengan Kualitas Tidur Ibu Hamil Trimester III di Wilayah Kerja Puskesmas Gading Kota Surabaya Tahun 2016

\begin{tabular}{|c|c|c|c|c|c|}
\hline \multirow{3}{*}{ Variabel Bebas } & \multirow{3}{*}{ Kategori } & \multicolumn{4}{|c|}{ Kualitas Tidur } \\
\hline & & \multicolumn{2}{|c|}{ Baik } & \multicolumn{2}{|c|}{ Buruk } \\
\hline & & $\sum$ & $\%$ & $\sum$ & $\%$ \\
\hline \multirow{3}{*}{ Umur } & $<20$ tahun & 1 & 50 & 1 & 50 \\
\hline & $20-35$ tahun & 14 & 46,7 & 16 & 53,3 \\
\hline & 35 tahun & 2 & 50 & 2 & 50 \\
\hline \multirow{2}{*}{ Pendapatan keluarga } & $<3.000 .000$ per bulan & 11 & 55 & 9 & 45 \\
\hline & $>3.000 .000$ per bulan & 6 & 37,5 & 10 & 62,5 \\
\hline \multirow{2}{*}{ Graviditas } & Kehamilan pertama & 4 & 57,1 & 3 & 42,9 \\
\hline & $>1$ kali hamil & 13 & 44,8 & 16 & 55,2 \\
\hline \multirow{3}{*}{$\begin{array}{l}\text { Gangguan } \\
\text { Kenyamanan Fisik }\end{array}$} & Tidak ada gangguan & 4 & 80 & 1 & 20 \\
\hline & Gangguan Ringan & 13 & 46,4 & 15 & 53,6 \\
\hline & Gangguan berat & 0 & 0 & 3 & 100 \\
\hline \multirow[t]{2}{*}{ Penyakit } & Tidak & 17 & 53,1 & 15 & 46,9 \\
\hline & $\mathrm{Ya}$ & 0 & 0 & 4 & 100 \\
\hline
\end{tabular}


melahirkan. Pengalaman melahirkan yang buruk dapat menjadi ketakutan tersendiri bagi ibu hamil. Pada 57,1\% ibu hamil yang baru pertama kali hamil atau bisa disebut dengan ibu primigravida mengalami kualitas tidur baik, pada ibu multigravida atau ibu yang lebih dari satu kali hamil 55,2\% diantaranya justru mengalami kualitas tidur yang buruk.

Pada hasil penelitian seluruh ibu hamil yakni 3 ibu hamil (100\%) yang memiliki gangguan kenyamanan fisik berat mempunyai kualitas tidur yang buruk. Pada gangguan kenyamanan fisik terdapat nilai kekuatan hubungan yang menunjukkan nilai 0,363 yang artinya terdapat hubungan rendah antara gangguan kenyamanan fisik dan kualitas tidur ibu hamil trimester III.

Selain gangguan kenyamanan fisik terdapat faktor lain seperti penyakit. Penyakit yang diderita ibu hamil merupakan faktor yang memengaruhi kualitas tidur ibu. Pada penelitian ini seluruh ibu hamil yakni 4 ibu hamil yang memiliki penyakit mempunyai kualitas tidur yang buruk, sedangkan 53,1\% ibu hamil yang tidak memiliki penyakit mengaku memiliki kualitas tidur yang baik. Hasil penelitian menunjukkan nilai kekuatan hubungan 0,334 yang artinya terdapat hubungan yang rendah antara penyakit dengan kualitas tidur ibu hamil trimester III.

\section{Hubungan Asosiasi Variabel Bebas dan Kualitas Tidur Ibu Hamil Trimester III}

Ukuran Asosiasi yang digunakan yakni Prevalence Ratio (PR). Prevalence ratio yakni untuk memperkirakan tingkat risiko gangguan kenyamanan fisik dan penyakit dengan kualitas tidur ibu hamil trimester III.

Tabel 6 Menunjukkan bahwa Prevalence ratio (PR) pada gangguan kenyamanan fisik berat memiliki risiko 5 kali lebih besar mengalami kualitas tidur yang buruk daripada ibu yang tidak memiliki gangguan kenyamanan fisik. Pada ibu yang memiliki gangguan kenyamanan fisik ringan
Tabel 6. Hubungan Asosiasi Variabel Bebas dengan Kualitas Tidur Ibu Hamil Trimester III di Wilayah Kerja Puskesmas Gading Kota Surabaya Tahun 2016

\begin{tabular}{lll}
\hline \multicolumn{1}{c}{ Variabel } & $\begin{array}{c}\text { Prevalence } \\
\text { Ratio }\end{array}$ \\
\hline $\begin{array}{l}\text { Gangguan } \\
\text { kenyamanan } \\
\text { fisik }\end{array}$ & $\begin{array}{l}\text { Terganggu berat } \\
\text { terhadap tidak } \\
\text { terganggu }\end{array}$ & 5 \\
\cline { 2 - 3 } & $\begin{array}{l}\text { Terganggu } \\
\text { ringan terhadap } \\
\text { tidak terganggu }\end{array}$ & 2,678 \\
\hline Penyakit & $\begin{array}{l}\text { Memiliki } \\
\text { penyakit } \\
\end{array}$ & \\
& $\begin{array}{l}\text { terhadap tidak } \\
\text { memiliki } \\
\text { penyakit }\end{array}$ & 2,13 \\
\hline
\end{tabular}

memiliki peluang risiko 2,678 kali lebih besar mengalami kualitas tidur yang buruk daripada ibu hamil yang tidak memiliki gangguan kenyamanan fisik. Faktor penyakit menjadi faktor yang harus diperhatikan bagi ibu hamil. Hasil penelitian menunjukkan ibu hamil yang memiliki penyakit memiliki risiko 2,13 kali lebih besar mengalami kualitas tidur yang buruk.

\section{PEMBAHASAN}

Hasil penelitian pada tabel 5 menunjukkan terjadinya kualitas tidur buruk mempunyai persentase yang hampir sama di semua usia, sedangkan sebagian besar ibu yang memiliki pendapatan keluarga kurang dari Rp 3.000.000 per bulan memiliki kualitas tidur yang buruk.

Status graviditas yang dimiliki ibu hamil juga menunjukkan persentase yang hampir sama untuk terjadi kualitas tidur yang buruk. Variabel lain yakni gangguan kenyamanan fisik menunjukkan persentasi yang tinggi untuk terjadi kualitas tidur yang buruk pada ibu dengan gangguan kenyamanan fisik berat, dan seluruh ibu hamil yang memiliki penyakir mempunyai kualitas tidur yang buruk. 


\section{Kualitas Tidur Ibu Hamil Trimester III}

Ibu hamil memerlukan sekitar delapan jam untuk tidur di malam hari, selain itu tidur siang juga dibutuhkan oleh ibu hamil. Ibu hamil terutama bila sudah memasuki Trimester III memerlukan istirahat seperti duduk dan bersantai di sela-sela melakukan kegiatan rutinnya. Ketika memasuki trimester III semakin banyak keluhan-keluhan yang dirasakan ibu sehingga akan mengganggu istirahat dan tidur (Siswosuhardjo, 2010).

Tabel 4 diketahui bahwa terdapat persentase yang hampir sama antara ibu hamil trimester III yang mempunyai kualitas buruk maupun ibu hamil yang memiliki kualitas tidur baik. Ibu hamil yang mempunyai kualitas tidur buruk yakni 19 ibu hamil $(52,8 \%)$ dan ibu hamil mempunyai kualitas tidur baik yakni sebanyak $17 \mathrm{ibu}$ hamil $(47,2 \%)$. Hal ini artinya proporsi kualitas tidur ibu hamil trimester III paling banyak yakni yang memiliki kualitas tidur yang buruk. Hal ini sejalan dengan penelitian yang dilakukan oleh Tsai et al (2011), pada 30 ibu hamil yang meneliti tentang kualitas tidur ibu hamil trimester III di Taiwan didapatkan 50\% dari ibu hamil mempunyai skor PSQI lebih besar dari 5. Skor kurang dari 5 menunjukkan ibu hamil memiliki kualitas tidur yang buruk.

Penelitian yang dilakukan oleh Mendell et al (2015), pada 2427 responden menyatakan bahwa $76 \%$ diantaranya mengalami kualitas tidur yang buruk. Seluruh responden menyatakan sering terbangun di malam hari, sebanyak $78 \%$ menyatakan tidur siang dan $57 \%$ menunjukkan adanya gejala insomnia. Gangguan tidur yang terjadi dapat berupa gangguan nafas, Restless Legs Syndrom atau gangguan saraf pada kaki, buang air kecil dan kesulitan untuk menemukan posisi tidur yang nyaman.

Penelitian yang dilakukan Lee (2004) menyatakan wanita yang tidur kurang dari 6 jam per malam memiliki kemungkinan menjalani operasi caesar 4,5 kali lebih besar. Ibu hamil disarankan tidur 8 jam per malam.
Sebanyak 52,8\% ibu hamil trimester III yang menjadi responden dalam penelitian ini mengaku tidur kurang lebih 5 jam per malam. Ibu hamil mengaku sering bangun di malam hari, hal ini berarti masih kurangnya jam tidur ibu hamil pada malam hari.

\section{Karakteristik Ibu Hamil}

\section{Umur}

Makin bertambah umur seseorang semakin dapat mengatur dalam menggunakan koping terhadap masalah yang dihadapi (Tamher dan Norrkasiani, 2009). Beberapa wanita memiliki pilihan untuk hamil di umur 30 tahun, namun perlu diperhatikan bahwa seiring dengan bertambahnya umur fungsi reproduksi wanita akan menurun (Detiana, 2010).

Hamil dan melahirkan dengan umur dibawah 20 tahun dapat menjadi risiko dalam kehamilan karena organ reproduksi yang belum matang. Usia di bawah 20 tahun dapat menjadi risiko terjadinya post partum blues yakni depresi pasca persalinan (Pitriani dan Andriyani, 2014).

Umur untuk hamil dan melahirkan paling baik yakni antara 20-35 tahun. Umur ini merupakan umur ideal sehingga dianggap memiliki risiko paling rendah terjadinya komplikasi untuk ibu dan anak (Rasjidi, 2014)

Tabel 1 menunjukkan bahwa sebanyak $83,3 \%$ responden berumur 20-35 tahun, sedangkan sisanya masuk dalam umur risiko tinggi (kurang dari 20 tahun dan lebih dari 35 tahun). Tabel 5 menunjukkan sebanyak $53,3 \%$ ibu hamil yang mempunyai umur ideal untuk hamil dan melahirkan justru mempunyai kualitas tidur yang buruk.

Pada ibu hamil yang memiliki umur risiko tinggi mempunyai persentase yang sama untuk kualitas tidur baik maupun buruk. Distribusi umur ibu hamil paling banyak terdapat pada umur 20-35 tahun sehingga variasi kualitas tidur paling banyak berada di usia tersebut. 
Pada usia ideal yakni 20-35 tahun ibu hamil memiliki risiko yang rendah terjadi komplikasi kehamilan karena organ reproduksi dan mental yang lebih matang. Dalam penelitian ini sebagian besar ibu hamil memiliki kualitas tidur yang buruk dikarenakan adanya faktor lain seperti gangguan kenyamanan fisik yang lebih dominan dirasakan oleh ibu hamil.

\section{Pendapatan Keluarga}

Pendapatan keluarga didapat dari pendapatan yang diperoleh baik dari suami dan istri yang bersumber dari kerja pokok maupun kerja sampingan. Kehamilan dan persalinan tentu membutuhkan persiapan yang matang dan membutuhkan biaya untuk perawatan sebelum melahirkan, biaya melahirkan, perlengkapan bayi, dan biaya masa depan anak, dan biaya-biaya lain sehingga harus dipersiapkan dengan sebaik-baiknya (Susanti, 2013). Pada ibu hamil dengan masalah ekonomi tentunya akan menjadi beban tersendiri bagi ibu, dan dapat menjadi sumber stressor pada ibu hamil. Stress yang dialami ibu hamil ini dapat memengaruhi kualitas tidur ibu hamil. Tabel 1 menunjukkan hasil bahwa 55\% ibu hamil yang memiliki pendapatan keluarga kurang dari sama dengan Rp 3.000.000 per bulan memiliki kualitas tidur yang baik.

Pada ibu hamil yang memiliki pendapatan keluarga kurang dari Rp 3.000.000 atau di bawah UMR dan dirasa tidak mampu secara financial telah diberikan fasilitas seperti Asuransi Badan Penyelenggara Jaminan Sosial (BPJS), Kartu Indonesia Sehat maupun asuransi lain yang memudahkan ibu hamil untuk mendapatkan layanan kesehatan dan kelahiran, sehingga kecemasan akan biaya kehamilan dan persalinan dapat teratasi.

\section{Graviditas}

Graviditas merupakan status kehamilan ibu. Graviditas dapat memengaruhi kualitas tidur ibu hamil, bila pada kehamilan yang pertama atau primigravida seorang ibu belum memiliki pengalaman untuk melahirkan sehingga merasa lebih cemas dalam menghadapi persalinan nantinya. Berbeda dengan primigravida, pada ibu yang sudah pernah melahirkan atau multigravida kecemasan yang terjadi dalam hal ini dapat lebih teratasi (Prasadja, 2009).

Tabel 1 menunjukkan sebanyak 80,6\% responden merupakan ibu hamil lebih dari satu kali (multigravida). Sebanyak 55,2\% Ibu hamil tersebut memiliki kualitas tidur yang buruk. Sebanyak 57,1\% ibu yang baru pertama kali hamil atau primigravida memiliki kualitas tidur yang baik. Penelitian yang dilakukan oleh Sreesupriya (2014), yang menyatakan tidak ada hubungan yang bermakna antara graviditas dengan kualitas tidur ibu hamil.

Banyaknya ibu multigravida yang mempunyai kualitas buruk ini dikarenakan terdapat faktor-faktor lain yang memengaruhi kualitas tidur ibu hamil. Faktor seperti cemas karena pengalaman buruk melahirkan lalu akan menambah tingkat kecemasan. Hal ini akan memengaruhi terhadap kualitas tidur ibu hamil trimester III.

\section{Gangguan Kenyamanan Fisik}

Kenyamanan merupakan perasaan yang sifatnya subjektif dan dirasakan seseorang terhadap lingkungan yang dinilai berdasarkan persepsi masing-masing individu. Pada ibu hamil trimester III dapat terjadi perubahan fisik yang dapat menimbulkan ketidaknyamanan selama kehamilan seperti timbul masalah pada saluran pencernaan, kelelahan, bengkak pada kaki, sesak nafas, sensitifitas kandung kemih dan nyeri punggung (Neil, 2007). Ketidaknyamanan fsisk yang dirasakan ibu ini umumnya akan semakin bertambah seiring dengan bertambahnya umur kehamilan (Aprilia, 2014).

Pada tabel 2 hasil Penelitian menunjukkan bahwa sebanyak $78 \%$ ibu hamil memiliki gangguan kenyamanan ringan yang artinya gangguan kenyamanan fisik yang dirasakan ibu hamil tidak 
mengganggu aktivitas sehari-hari ibu hamil seperti bekerja, tidur dan lain-lain. Sebanyak $53,6 \%$ ibu hamil yang memiliki gangguan kenyamanan fisik ringan menyatakan memiliki kualitas tidur yang buruk. Hampir seluruh dari ibu hamil yang tidak mengalami gangguan kenyamanan fisik menyatakan bahwa memiliki kualitas tidur yang baik. Hal ini sesuai dengan yang diungkapkan Aprilia (2014) bahwa ketidaknyamanan fisik yang dirasakan oleh ibu selama kehamilan akan membuat ibu hamil kesulitan untuk tidur di malam hari.

Ibu hamil yang memiliki gangguan kenyamanan fisik berat atau gangguan kenyamanan fisik yang dirasakan ibu hingga mengganggu aktivitas sehari-hari (bekerja, tidur dan lain-lain). Pada penelitian ini gangguan kenyamanan fisik berat memiliki risiko 5 kali lebih besar mengalami kualitas tidur yang buruk daripada ibu yang tidak memiliki gangguan kenyamanan fisik.

Pada ibu hamil yang memiliki gangguan kenyamanan fisik ringan berisiko 2,678 kali lebih besar mengalami kualitas tidur yang buruk daripada ibu hamil yang tidak memiliki gangguan kenyamanan fisik. Hal ini artinya risiko akan semakin bertambah pada ibu hamil yang memiliki gangguan kenyamanan fisik berat. Pada ibu yang mengalami gangguan kenyamanan fisik berat, gangguan yang dirasakan seperti sering buang air kecil, nyeri punggung, maupun kram kaki sehingga mengganggu aktivitas ibu hamil dan juga kualitas tidur ibu hamil.

Kekuatan hubungan antara gangguan kenyamanan fisik dan kualitas tidur ibu hamil trimester III menunjukkan nilai 0,363. Kekuatan hubungan 0,363 artinya terdapat kekuatan hubungan yang rendah. Penelitian ini sejalan dengan penelitian yang dilakukan oleh Iriana (2013), yang menyatakan terdapat hubungan yang bermakna antara gangguan kenyamanan fisik dan kualitas tidur ibu hamil di Puskesmas Helvetia Medan. Ibu Hamil yang menjadi responden sebagian besar mengeluhkan adanya buang air kecil yang semakin sering, nyeri pinggang dan cepat lelah akan tetapi tidak mengganggu aktivitas sehari-hari (bekerja, tidur dan lainlain) ibu hamil.

Penelitian yang dilakukan Suzuki (2009), diklinik antenataldi Sapporo Medical College Hospital Jepang menyatakan bahwa penyebab paling sering ibu hamil yang mengalami perubahan tidur adalah frekuensi kencing, sakit punggung atau sakit di pinggul, yang umumnya dirasakan oleh ibu hamil trimester III, ketidaknyamanan fisik yang dirasakan akan semakin berat, sejalan dengan usia kehamilan.

\section{Penyakit}

Penyakit adalah suatu keadaan tidak normal dari tubuh maupun psikis yang sifatnya objektif karena masing-masing memiliki parameter tertentu (Ismail, 2009). Gejala yang dirasakan dari penyakit dapat mengganggu frekuensi tidur Ibu hamil contohnya nyeri. Tabel 3 didapatkan hasil bahwa dari sebanyak 36 ibu hamil trimester III yang menjadi responden 4 orang (11\%) diantaranya mempunyai penyakit yakni Asma, Hipertensi dan Anemia.

Tabel 5 menunjukkan 4 orang ibu hamil yang memiliki penyakit tersebut seluruhnya (100\%) mempunyai kualitas tidur yang buruk, demikian pula 53,1\% ibu hamil yang tidak mempunyai penyakit mempunyai kualitas tidur yang baik. Ibu yang memiliki penyakit mempunyai risiko 2,13 kali lebih besar mengalami kualitas tidur yang buruk daripada ibu yang tidak memiliki penyakit.

Hasil analisis menunjukkan kekuatan hubungan antara penyakit dengan kualitas tidur ibu hamil trimester III menunjukkan nilai 0,334. Hasil kekuatan hubungan tersebut artinya terdapat kekuatan hubungan yang rendah.

Penelitian ini sesuai dengan penelitian yang dilakukan oleh Leemakers (2012), yang menyatakan bahwa terdapat hubungan antara kualitas tidur dengan penyakit dalam 
kehamilan. Diantaranya asma, diabetes maupun hipertensi. Demikian juga penelitian yang dilakukan oleh Sharma (2004), yang menyatakan Restless Legs Syndrom dapat menjadi penyebab signifikan dari gangguan tidur pada ibu hamil. Restless Legs Syndrom merupakan gangguan neurologis ditandai dengan rasa tidak nyaman pada kaki dan umum terjadi pada ibu hamil.

\section{SIMPULAN}

Pada Ibu hamil yang menjadi responden dalam penelitian ini memiliki karakteristik yakni sebagian besar berada di umur ideal 20-35 tahun dengan pendapatan keluarga lebih dari sama dengan 3.000 .000 per bulan. Sebanyak $80,6 \%$ responden merupakan ibu multigravida atau lebih dari satu kali hamil sehingga telah memiliki pengalaman melahirkan sebelumnya. Kualitas tidur buruk yang terjadi pada ibu hamil dipengaruhi oleh faktor lain seperti gangguan kenyamanan fisik maupun ketakutan ibu hamil menjelang persalinan.

Risiko mengalami kualitas tidur buruk meningkat pada ibu hamil yang memiliki gangguan kenyamanan fisik berat. Pada Ibu hamil yang mempunyai penyakit meningkatkan risiko untuk mengalami kualitas tidur buruk. Ibu hamil yang memiliki penyakit berisiko 2,13 kali lebih besar mempunyai kualitas tidur yang buruk daripada ibu hamil yang tidak memiliki penyakit.

Dari penelitian ini diharapkan bisa dijadikan sebagai masukan untuk tenaga kesehatan khususnya bidan maupun staf Kesehatan Ibu dan Anak (KIA) untuk meningkatkan peran serta dukungan suami dalam pemantauan kesehatan ibu hamil. Petugas kesehatan juga selalu memonitoring kesehatan ibu hamil Trimester III pada saat pemeriksaan kesehatan ibu hamil atau Antenatal Care (ANC). Pemeriksaan ini termasuk mengenai kualitas tidur ibu hamil trimester III dan penyebab ibu hamil mengalami gangguan tidur seperti gangguan kenyamanan fisik maupun adanya penyakit yang diderita ibu hamil.

Adanya hasil penelitian ini dapat menjadi masukan bagi peneliti selanjutnya untuk meneliti faktor yang menyebabkan ibu dengan pendapatan lebih dari Rp 3.000.000 per bulan memiliki kualitas tidur buruk dan fakor gangguan kenyamanan lingkungan seperti suhu.

\section{DAFTAR PUSTAKA}

Andari, P., 2013. Kualitas Tidur dan Pola Tidur Ibu Hamil Trimester III yang Datang Memeriksakan Kehamilan di klinik Mariati Kecamatan Medan Marelan Tahun 2013.Skripsi. Universitas Sumatera Utara. Tersedia di <repository.usu.ac.id/ bitstream/123456789/52034/7/Cover. pdf.> [Diakses tanggal 1 April 2016]

Aprilia, A. 2014. Diary Ibu Hamil. Jakarta: Kawan Pustaka.

Asmadi. 2008. Teknik Prosedural Keperawatan: Konsep dan Aplikasi Kebutuhan Dasar Klien. Jakarta: Penerbit Salemba.

Ayudhitya, D., Tjuatja, I. 2014. Health is Easy. Jakarta: Penebar Plus +.

Detiana, P. 2010. Hamil Aman dan Nyaman di atas Umur 30 Tahun. Yogyakarta: Penerbit Media Pressindo.

Dinas Kesehatan Kota Surabaya. Profil Kesehatan Kota Surabaya. 2015.

Dinas Kesehatan provinsi Jawa Timur. Profil Kesehatan Jawa Timur. 2014

Emilia, O. 2010. Tetap Bugar dan Energik selama hamil. Jakarta: Agromedia Pustaka.

Iriana, D.K. 2013. Hubungan Kecemasan dan gangguan kenyamanan Fisik terhadap kualitas tidur ibu hamil di Puskesmas Helvetia medan. Skripsi. Tersedia di <http://repository.usu.ac.id/ bitstream/123456789/40399/7/Cover. pdf $>$ [ Diakses tanggal 14 desember 2016].

Ismail, G. 2009. Sehat Tanpa Obat. Jakarta: Grasindo. 
Komalasari, D., Maryati I., Koeryaman, M. 2012. Hubungan antara tingkat kecemasan dengan kualitas tidur pada ibu hamil trimester III di puskesmas jatinangor Kabupaten. Skripsi.Universitas Padjajaran. Tersedia di <http://jurnal.unpad.ac.id/ ejournal/article/viewFile/727/773> [Diakses tanggal 10 Desember 2016]

Lee, K., Gay, C.L. 2004. Sleep in Late Pregnancy Predict Length of Labor and Type of Delivery. American Journal of Obstetrics and Gynecology. Vol. 191. Nomor 6. Halaman 2041-2046. Tersedia $d i$ : https://www.ncbi.nlm.nih.gov/labs/ articles/15592289/. [Diakses tanggal 8 Agustus 2016]

Leemakers, E.,Voort,A., Gaillard, R., Hofman, A., Jongste, J., Jaddoe, V., et al.2012. Sleep quality as a confounding factor of maternal weight and preschool wheezing. European Respiratory Journal. Vo1. 43. Hal. 1543-1545. Tersedia di <http://erj.ersjournals.com/ content/43/5/1543> [ Diakses tanggal 9 Desember 2016]

Mindell, J., Cook, R., Nikolovski, J. 2015. Sleep patterns and sleep disturbances across pregnancy. J. Sleep. Vol. 16. No.4Hal.483-488. Tersediadihttps://www. researchgate.net/publication/272095499 Sleep_patterns_and_sleep_disturbances across_pregnancy. [ Diakses tanggal 20 desember 2016]

Neil, W. 2007. Panduan Lengkap Perawatan Kehamilan. Jakarta: Dian Rakyat.

Okun, M. 2011. Poor Sleep Quality is Associated with Preterm Birth.J. Sleep. Vol 34. Nomor 11.. Halaman 1493-1498 Tersedia di http://www.journalsleep.org/ ViewAbstract.aspx?pid=28329[Diakses tanggal 10 Oktober 2016]

Pitriani. R., Andriyani, R. 2014. Panduan Lengkap Asuhan Kebidanan Ibu Nifas Normal (Askeb III). Yogyakarta: Deepublish.
Prasadja, A. 2009. Ayo Bangu dengan Bugar karena Tidur yang Benar. Bandung: Hikmah.

Rasjidi, I. 2014. Panduan Kehamilan Muslimah. Jakarta: PT. Mizan Republika.

Rezaei, E. 2013. Quality of Life in Pregnant Women with Sleep Disorder. Journal of Family and Reproductive Health. Vol. 7. Nomor 2. Halaman 87-93 Tersedia di <https://www.ncbi.nlm.nih.gov/pme/ articles/PMC4064778/> [Diakses tanggal 14 desember 2016]

Sharma, S. 2004. Sleep and Its Disorders in Pregnancy. Winconsin Medical Journal. Vol. 103. Nomor 5. Halaman 48-52. Tersedia di: <https://www. wisconsinmedicalsociety.org/_WMS/ publications/wmj/pdf/103/5/48.pdf $>$ [ Diakses tanggal 9 Desember 2016]

Siswosuhardjo, S., Chakrawati, F. 2010. Panduan Super Lengkap Hamil Sehat. Jakarta: Penebar Plus + .

Sreesupriya. 2014. A Study on Sleep Disturbances Among Antenatal Women Attending A Tertiary Care Hospital, in Chennai, Tamilnadu. Indian Journal of Applied Research. Vol 4. Nomor 10. Halaman 426-428. Tersedia di https:// www.worldwidejournals.com/indianjournal-of-applied-research-(IJAR)/file. php?val=October_2014_1413535698_ _132.pdf[ Diakses tanggal 14 desember 2016]

Sugiyono. 2009. Metode Penelitian Kuantitatif dan Kualitatif. Bandung: Alfabeta.

Susanti, N. 2013. Psikologi Kehamilan. Jakarta: Penerbit Buku kedokteran EGC.

Suzuki. 2009. Sleeping Patterns During Pregnancy in Japanese Women. Journal of Psychosomatic Obstertrics \& Ginecology. Vol. 15. Nomor 1. Halaman 19-26. 
Tersedia di <https://www.ncbi.nlm.nih.gov/ pubmed/8038885> [Diakses tanggal 13 Desember 2016

Swarjana, I.,K. 2012. Metode Penelitian kesehatan. Yogyakarta: ANDI OFFSET

Tamher, S., Noorkasiani. 2009. Pendidikan Usia Lanjut dengan Pendekatan Asuhan Keperawatan. Jakarta: Salemba Medika.

Tsai, S., Khuo, L., Lai, Y.,Lee, C. 2011. Factors Associated With Sleep Quality in Pregnant Women: A Prospective Observational Study. Nursing Research. Vol 60. Nomor 6. Halaman 405-412.Tersedia di: $<$ http:// journals.lww.com/nursingresearchonline/
Abstract/2011/11000/Factors Associated_With_Sleep_Quality_in_ Pregnant.6.aspx $>$ [ Diakses tanggal 20 desember 2016]

Williams, M., Miller, R., Qiu, C., Cripe, S., Gelaye, B., Enquobahrie, D. 2010. Associations of Early Pregnancy Sleep Duration with Trimester-Specific Blood Pressures and Hypertensive Disorders in Pregnancy.J.Sleep. Vol. 33. Nomor 10. Halaman 1363-1371. Tersedia di: https://www.ncbi.nlm.nih.gov/pme/ articles/PMC2941423/[ Diakses tanggal 8 Agustus 2016] 